\title{
Model Implementation of Flood Control Policies Based on Community Participation (Study of Policy Implementation in Flood Hazard Management in Purwantoro Village, Malang City)
}

\author{
Bambang Nugroho* Agus Sholahuddin Laksni Sedyowati \\ University Of Merdeka Malang
}

\begin{abstract}
The purpose of this study for this study aims to create a model for implementing community participation-based flood control policies to mobilize people to play an active role in flood control programs and environmental management in densely populated urban areas. To achieve these objectives, this study has a specific objective, namely to describe and analyze a model of flood management based on community participation in urban areas in Malang City based on Malang City Regulation No. 5 of 2016. The method of this study uses a qualitative approach that is descriptive. The community participation-based flood control policy model is a public participation-based public policy implementation model that is not only focused on overcoming flood problems but also provides benefits to the surrounding community in the form of job opportunities and provides additional economic value in the form of harvested eggplant, chili, catfish, and tomato. Thus, this control policy model is a community participation-based flood control policy with a new approach in the form of a synergy of 4 (four) stakeholders, namely: government, academia, business and local communities.
\end{abstract}

DOI: $10.7176 / \mathrm{JESD} / 12-12-08$

Publication date:June $30^{\text {th }} 2021$

\section{Introduction}

The paradigm of sustainable development as a global demand makes cities in Indonesia re-evaluate the development that has been carried out by balancing economic, social and ecological aspects. Urban economic growth and community welfare have increased, but the problem of areas being inundated or flooded has also increased. Malang City, which is one of the cities in East Java Province, is located in a highland area with varying land surface slopes, however every rainy season at certain points in almost all areas of the city always experiences inundation caused by non-technical fan technical factors. Technical factors include the overflowing of rivers and poor drainage systems due to the expansion of built-up areas, reducing infiltration areas, silting of channels and narrowing of channel sections due to illegal structures, blockage of drains due to garbage, and flooding due to changes in land cover from upstream areas. Meanwhile, non-technical factors that cause flooding include community behavior that does not support flood control efforts, both flood prevention and control. In solving the problem of flooding, an integrated flood control policy is needed, an integrated flood control process through a land and water resource management approach, and a disaster area management in a watershed with the aim of maximizing the benefits of a floodplain and minimizing loss of life and property damage. objects from flooding (Green et al., 2004).

Government institutions in Malang City related to flood control have formulated a flood control policy with a community participation approach in flood mitigation, placing the community in the position of the perpetrator and the beneficiary of the process of finding solutions to solve flood problems. The community has also independently carried out flood prevention efforts, including repair and maintenance of local channels, increased resilience and adaptation to the risk or danger of inundation / flooding. However, these efforts are only carried out by a small part of the community and have not been evenly distributed in all areas, especially in flood-prone points, so they have not yielded significant results. On the other hand, the problem of flooding is a problem that reaches all levels of society.

This study aims to create a model for implementing flood control policies based on community participation to mobilize people to play an active role in flood control programs and environmental management in densely populated urban areas. To achieve these objectives, this study has a specific objective, namely to describe and analyze a model of flood management based on community participation in urban areas in Malang City based on Malang City Regulation No. 5 of 2016.

\section{Literature Review}

\subsection{Policy Implementation}

Policy implementation is an important aspect of the entire policy process. In this connection, Udoji (1981: 59) emphasizes that the implementation of policy is something important, even far more important than policy making. Wisdom will be just a dream or a good plan tucked away in the archives if not implemented. Then in implementing 
policies / programs, especially those involving many government organizations / agencies or various levels, according to Abdul Wahab (2008: 63) it can be seen from 3 (three) points of view as follows: (1) policy initiators / policy makers, (2) Implementing officials in the field, and (3) individual actors outside the government agencies to whom the program is aimed, namely the target group. Public policy implementation is a series of activities after a policy is formulated and stipulated. Policy implementation refers to the mechanisms, resources, and relationships related to the implementation of policy programs (Mthethwa, 2012). Without its implementation, the policies that have been set will be in vain. Therefore, policy implementation has an essential position in public policy. According to Nugroho (2003: 158), policy implementation is, in principle, a way for a policy to achieve its goals (neither more nor less). Furthermore, Nugroho (2003: 158) argues that a good planning or policy will play a role in determining good results. The concept (which is supported by future data and information) contributes about 60 percent to the success of the policy and about 40 percent to the implementation which must be consistent with the concept.

\subsection{Public Policy Implementation}

In the implementation of public policies, there are two choices of steps that can be taken, namely directly implementing them in the form of programs or through the formulation of derivative policies or derivatives of these public policies. In principle, policies aim to intervene. Thus, the implementation of the policy in the right package is the intervention action itself. Broadly speaking, policy implementation is described as what is clearly defined by the policy maker (government) which will have a particular impact. Jann \& Wegrich (2007) states that policy implementation will include the following core elements: (1) Specific program details, namely how and where the institution or organization should run the program, and how the law or program is interpreted, (2) Resource allocation, namely how the budget is distributed, personnel who will implement the program and the organization responsible for program implementation, (3) Decisions, namely how decisions will be made. From this statement it can be understood that policy implementation actually does not only concern the behavior of the agencies or institutions that are responsible for implementing the program and creating compliance for the target group, but also regarding the network of political, economic and social forces that influence the various parties involved and In the end, it will have an impact, both expected and unexpected (intended risk and unintended risk). This should always be considered in the implementation process. Thus it can be argued that the implementation of government policies is influenced by the social conditions of society, economic conditions, political power networks and administrative instruments for implementing the policies themselves. Referring to the above statements, it can be concluded that policy implementation is a stage of activities / activities / programs in implementing policy decisions made by individuals / officials, groups, government, society, and / or private sector in order to achieve the goals set out in the decision. policies that will affect the final outcome of a policy.

\subsection{Actors in Public Policy Implementation}

In the policy process, according to Jones in Abdul Wahab (2008: 29), there are at least 4 (four) groups or types of actors (actors) involved, namely: the rationalist group, the technical group, the incremental group, and the reformist group. However, it should be remembered that on certain occasions and for certain types of issues it is possible that only one or two groups of actors are influential and actively involved. The roles played by these four groups of actors in the policy process, the values and goals they pursue and the working styles of the actors differ from one another.

Table 1. Schemes of Actors Involved in the Policy Process and Their Behaviors

\begin{tabular}{|c|l|l|l|l|l|}
\hline \multicolumn{1}{|c|}{ Role } & \multicolumn{1}{|c|}{ Values } & \multicolumn{1}{c|}{ Goal } & Work Style & \multicolumn{1}{c|}{ Critics } \\
\hline Rasionalist & $\begin{array}{l}\text { Policy Analyst } \\
\text { / Planner }\end{array}$ & Method & Predetermined & Don't \\
\hline Technician & $\begin{array}{l}\text { Expert / } \\
\text { Specialist }\end{array}$ & Education / Skills & $\begin{array}{l}\text { Set by another } \\
\text { party }\end{array}$ & Explicit & $\begin{array}{l}\text { narrow- } \\
\text { minded }\end{array}$ \\
\hline Incrementalist & Politicians & Status quo & $\begin{array}{l}\text { Due to new } \\
\text { demands }\end{array}$ & bargainer & Conservative \\
\hline Reformers & Negotiator & $\begin{array}{l}\text { Social } \\
\text { transformation }\end{array}$ & $\begin{array}{l}\text { Due to urgent } \\
\text { matters }\end{array}$ & Activist & $\begin{array}{l}\text { Unrealistic } \\
\text { unfamiliar } \\
\text { compromise }\end{array}$ \\
\hline
\end{tabular}

Source: Jones in Abdul Wahab (2008: 33)

\subsection{Factors Affecting Policy Implementation}

Policy implementation is a stage that lies between the formulation of policies and the results or consequences (Output and out comes) generated by the policy. Edward III (In Widodo, 2001) states that there are four factors that interact with each other in policy implementation, namely communication factors, resource factors, disposition 
factors, or attitudes, and organizational factors. Society participation Adisasmita (2006) states that the participation of community members is the involvement of community members in development. The involvement of community members in development includes activities in planning and implementing development programs or projects carried out in the local community, which is one form of active community empowerment that is oriented towards achieving the results of development carried out in the community that is effective and efficient both from the input or input aspect. (HR, funds, equipment / facilities, data, plans and technology), from the process aspect (implementation, monitoring and supervision), from the output aspect (effective and efficient target achievement). Based on this definition, Ndraha (1994) concluded that there are three important elements of participation, namely: (1) participation means mental and emotional involment, (2) motivates persons to contribute to the situation, and (3) encourage people to accept responsibility in activity. Based on some of these opinions, the community can consciously be in the development process in order to achieve a better condition than before. As stated by Conyers (1982), there are three main reasons why community participation is very important, namely: (1) Community participation is a measure to obtain information about the conditions and needs of local communities, without the presence of development programs and projects. the project will fail, (2) The community will trust the project or development programs more if they feel involved in the preparation and planning process, because they will know more about the project. (3) There is an assumption that it is a democratic right if the community is involved in the development of the community itself (Supriatna, 2000). In this regard, it can be seen that community participation is carried out from the planning, implementation, acceptance, utilization and maintenance stages, development of development results as well as supervision and assessment of development results. To realize the success of development, initiative and creativity of community members born from awareness and responsibility as human beings who live in society and are expected to grow as a participation. Participation is an active community involvement. The community can also be involved in the process of determining direction, the development policy strategy implemented by the government. This mainly takes place in the political process as well as in the social process, the relationship between interest groups in society so that it gets support in its implementation.

\subsection{Integrated Flood Management}

Integrated flood management is an integrated process of flood management through a land and water resource management approach, coastal coastal areas, and disaster area management in a watershed with the aim of maximizing the benefits of floodplain areas and minimizing loss of life and property damage from flooding (Green et al. 2004). Integrated flood management is an integral measure that directs all stakeholders from sub-sector flood management to cross-sectors (Kodoatie \& Sjarief, 2006).

\section{Research Methods}

This research was conducted using a social aspect approach with qualitative methods, the research design was in the form of an indeph interview. As a support, observation and documentation were used. In the data collection process, the methods commonly used are observation and interviews. In-depth interviews were conducted to determine the willingness of the community to live in the floodplain, losses due to flooding that occurred during the last 10 years, and community values used in their flood resilience system. Field observations were made to understand the existing community flood resilience system, the interaction of local communities with local governments and related agencies, as well as the creativity, innovation and potential of local communities in developing cost effectiveness. The research was conducted in Malang city with the consideration that the city already represents the complex characteristics of urban communities in Indonesia, which consists of many ethnic groups from all parts of Indonesia as well as various levels of society and the diversity of the business world, as well as representing the characteristics of the city.

The research is focused on the community participation-based flood control policy model which includes: (1) Affected Interests, (2) Types of benefits, (3) Expected Degree of Change, (4) Location of Decision Makers, (5) Funding Sources, and (6) Program Implementer Data analysis technique

The data analysis technique in this study uses data analysis techniques on the website developed by Miles, Huberman and Saldana (2014), namely analyzing data in three steps: data condensation, presenting data (display data), and drawing conclusions or verification ( conclusion drawing and verification).

\section{Result and Finding}

\subsection{Community Participation Based Flood Management Policy Implementation Model}

The community participation-based flood control policy model is to mobilize the community around a channel or river to actively participate in efforts to control rain runoff, which can also provide benefits in the form of: (1) Physical value, such as the availability of green open space that can be enjoyed by the community; (2) Social value, in the form of a place for recreation such as taking a walk or just sitting around relaxing, (3) Economic value, in the form of crop yields, as well as increasing visits to the area. This model is not only focused on overcoming the problem of flooding / inundation, but also can provide benefits to the socio-economy of the surrounding 
community. This model is adopted from the concept of integrated flood management that has developed globally, especially in Europe and Australia for the last decade. The involvement and active participation of all stakeholders is a major factor in the success of the model. Malang city government as the coordinator of socialization and development. Academics as coordinator of planning, training and quality assurance. Entrepreneurs contribute to development and implementation activities. The community as program implementers is equipped with adequate knowledge and skills in order to implement technology.

Interests Affected Based on the analysis of the Affected Interests in the implementation of the flood control policy model, the following findings can be formulated: Finding 1: The involvement and active participation of all stakeholders (government, community, and universities) is a major factor in the success of the flood control policy model.

\subsection{Types of Benefits}

Based on the mindset and activities that exist in the community, it is clear that the model program for flood control is based on community participation: First, it can empower the community to independently have resistance to flood risks. And second, it can change the people's mindset that controlling rain runoff in an area is the obligation of the people in the area itself, with facilitation from the Malang City PUPR Office with assistance from academics. The benefits that are felt in the flood management policy besides solving the problem of flooding also provide benefits: (1) providing environmental impacts such as the availability of green open spaces that can be enjoyed by the whole community. (2) The social environment for the community. (3) Opening up livelihood opportunities for the surrounding community and providing additional economic value.

Based on the discussion on the types of benefits in implementing a flood control policy model, the following findings can be formulated: Finding 2: The benefits felt in implementing the flood control policy model besides solving the flood problem, also provide physical, social and economic growth benefits for the local people.

\subsection{Expected Degree of Change}

The flood control policy model can provide benefits and benefits to the surrounding community, because the community maintains and controls cleanliness so that inundation or flooding does not occur again and the balance of the ecosystem is maintained. Based on the discussion of the expected degree of change in the implementation of the flood control policy model, the following findings can be formulated: Finding 3: The degree of change expected in the implementation of the flood control policy model is to create an environment that is free of flooding and standing water that can have an impact on the physical, social and economic aspects of the community.

\subsection{Decision Maker Location}

Operations and maintenance of the results of the implementation of community participation-based flood control policies carried out by involving the role of the community. Based on the discussion on the Location of Decision Makers in implementing the flood control policy model, the following findings can be formulated: Finding 4: The location of the decision maker in implementing the flood control policy model is implemented by the PUPRPKP Office of Malang City by involving the role of the community in creating an environment that is free of floods and stagnant water that can have an impact on the community's physical, social and economic.

\subsection{Sources of Funds for Financing}

The implementation of the flood control policy model must be supported by supportive resources so that its implementation can run smoothly. Therefore, infrastructure development that is carried out in stages must be carried out continuously with a good management mechanism, so that any flood control policies in the area can be implemented properly. Based on the discussion on the Sources of Funds for Financing in the implementation of the flood control policy model, the following findings can be formulated: Finding 5: Policy implementation Flood control is needed, considering that the source of funds for flood management requires a large amount of money, while the PUPRPKP Agency's ability to build flood control infrastructure is limited.

\subsection{Program Implementer}

In implementing flood control policies, the PUPRPKP Office has a decisive role. In the PUPRPKP Office, there is a good interaction between the authorized official and the apparatus as the implementer of policy implementation. Flood control can be implemented properly because the PUPRPKP Office has an adequate organizational structure. In policy implementation, the organizational structure becomes a place of interaction, where the apparatus or authorized executing officer manages policy implementation with a variety of activities. Thus basically the organizational structure is a system of formal relationships between tasks and authorities that control and coordinate resources to achieve goals. Based on the discussion of Program Implementers in implementing the flood control policy model, the following findings can be formulated: Finding 6: Implementing the flood control policy model involves a synergy between the PUPRPKP Office as the main actor, the community and the 
University as a supporting actor.

Based on these 6 findings, minor proposition was formulated as follows: The degree of change expected by involving the active participation of all stakeholders in the implementation of the flood control policy model, in addition to solving the flood problem, also creates a flood-free environment that can have a physical, social impact. and the economy of the community.

Based on the formulation of propositions 1,2,3, and 4, major propositions can be formulated as follows: The flood control policy model with a clear division of tasks among implementers, commitment to completing on time, and active participation of all stakeholders are able to create a free environment. floods that can have an impact on physical, social and spur economic growth for the community.

\section{Conclusion}

Based on the results of the analysis of existing field data findings, the following conclusions can be stated: A flood control policy model with a clear division of tasks between implementers, commitment to completion on time, and active participation of all stakeholders is able to create a flood-free environment that can have physical, social impacts and spur economic growth for the community. This flood control policy model is a model for implementing public policies based on community participation that is not only focused on overcoming the problem of flooding / inundation but can also provide physical, social and economic benefits and benefits to the surrounding community. Flood control policy model based on community participation with a new approach in the form of a synergy of 4 (four) stakeholders, namely: government, academics, businessmen and local communities. The innovative community-based flood control policy model is one of the infrastructures for the community environment because of its function to drain surface water that comes from rainwater as soon as possible to the receiving water body and then processed to achieve benefits for the surrounding community. The innovative concept of the flood control policy model is included in the ecodrainage concept, which is the sustainable handling of urban drainage systems, paying attention to the conditions and carrying capacity of the environment which has the principle of absorbing as much water as possible into the soil and maintaining the ecosystem and showing that the use of simple flood control technology is easy. operated, natural and low cost by restoring land function according to its natural function is effective in flood control rather than the use of high technology engineering. This concept can be replicated elsewhere, with the use of technology adapted to local land conditions and hydrometeorology.

\section{References}

Aan Komariah dan Djam'an Satori, 2010. Metodologi Penelitian. Kualitatif. Bandung : Alfabeta.

Abdul Wahab, Solichin. 2008. Analisis Kebijaksanaan dari Formulasi ke Implementasi Kebijaksanaan Negara. Bumi Aksara: Jakarta.

Adisasmita, Raharjo. 2006. Pembangunan Pedesaan dan Perkotaan. Yogyakarta : Graha ilmu. Ahmad, P, Partanto dan M. Dahlan Al Barry. 1994. Kamus Ilmiah Popular. Surabaya: Arloka.

Arikunto, S. 2002. Metodologi Penelitian Suatu Pendekatan Proposal. Jakarta: PT. Rineka Cipta.

Asdak, Chay. 2002. Hidrologi Dan Pengelolaan Daerah Aliran Sungai. Yogyakarta : Gajah Mada University Press.

A. Strauss and J. Corbin. 2015. Qualitative Research; Grounded Theory Procedure and Techniques. London: Sage Publication.

Azhari, Akyas. 2004. Psikologi Umum dan Perkembangan. Jakarta Selatan: Penerbit Teraju.

Basrowi dan Suwandi. 2008. Memahami Penelitian Kualitatif. Jakarta: Rineka Cipta.

Brigham, J. C. 1991. Social Psychology Edisi Kedua. New York : Harper. Colling Publisher Inc.

Cohen, JM, \& N.T. Uphoff. 1977. Rural Development Participation. New York : Cornell University RDCCIS.

Conyers, D. 1982. An Introduction to Social Planning in the Third World. New York: John Wiley and Sons.

Coryanata, Isma. 2012. Akuntabilitas, Pertisipasi Masyarakat dan Transparansi Kebijakan Publik Sebagai Pemoderasi Hubungan Pengetahuan Dewan Tentang Anggaran Dan Pengawasan Keuangan Daerah. Jurnal Akuntansi dan Investasi Vol 12 No. 2. Bengkulu : Fakultas Ekonomi.

Creswell, John W. 2015. Penelitian Kualitatif \& Desain Riset. Yogyakarta : Pustaka Pelajar.

Denzin, Norman K. dan Yvonna S. Lincoln (eds.). 2011. Handbook of Qualitative Research. Terj. Dariyatno dkk. Jogjakarta: Pustaka Pelajar.

Dunn, W. N. (2003). Pengantar Analisis Kebijakan Publik. Yogyakarta : Gadjah Mada University Press.

Dwijowijoto, Ryant Nugroho. 2003. Kebijakan Publik Formulasi, Implementasi dan Evaluasi. Jakarta: PT. Elex Media Komputindo.

Islamy, I. (2010). Prinsip-Prinsip Perumusan Kebijakan Negara. Jakarta: Bumi Aksara.

Jann, W., \& Wegrich, K. (2007). Theories of the Policy Cycle. In F. Fischer, G. J. Miller, \& M.

S. Sidney, Handbook of Public Policy Analysis Theory, Politics, and Methods (pp. 43- 62). New York: CRC Press Taylor \& Francis Group.

Jones E E \& Davis K E. From acts to dispositions: the attribution process in person Perception. Advances in 
experimental social psychology. (L. Berkowitz, ed.) New York : Academic Press, 1965. Vol. II, p. 219-266. (Duke University, Durham, NC]

Kodoatie, R.J. dan Sugiyanto. 2002. Banjir, Beberapa Penyebab dan Metode. Pengendaliannya dalam Perspektif Lingkungan. Yogyakarta : Pustaka Pelajar.

Korten, David C, 1993. "Growth for Whom? Rethinking Foreign Aid, Development, and the Meaning of Human Progress.’Dalam World Business Academy Perspectives, 7/3.

Ligal, S. 2008. Pendekatan Pencegahan dan Penanggulangan Banjir. Jurnal Dinamika Teknik Sipil Volume 8, No. 2 Juli 2008.

Linton, Ralph. 1968. The Study of Man: an Introduction. New York: Appleton-. Century. Lofland, John \& Lyn.H. Lofland. 1984. Analyzing Social Settings. California: Wadsworth.

Miles, M.B, Huberman,A.M, dan Saldana,J. 2014. Qualitative Data Analysis, A. Methods Sourcebook, Edition 3. USA: Sage Publications

Moleong, L. J. 2010. Metodologi Penelitian Kualitatif. Bandung : Remaja Rosda Karya.

Mthethwa, R. M. (2012). Critical Dimensions for Policy Implementation. African Journal of Public Affairs, 5(2), $36-42$.

Nakamura, Robert T. dan Frank Smallwood. 1980. The Politics of Policy Implementation. New York : St. Martins Press.

Ndraha, Taliziduhu. 1989. Konsep Administrasi Dan Administrasi Di Indonesia. Jakarta: Bina Aksara

Ndraha, Taliziduhu. 1994. Manajemen Pemerintahan, Pembangunan dan Pembinaan Masyarakat (MP3M) di Lingkungan Departemen Dalam Negeri. IIP: Jakarta.

Pülzl, H., \& Treib, O. (2007). Implementing Public Policy. In F. Fischer, G. J. Miller, \& M. S. Sidney, Handbook of Public Policy Analysis Theory, Politics, and Methods (pp. 89-107). New York: CRC Press Taylor \& Francis Group.

Sadhana, Kridawati. 2011. Realitas Kebijakan Publik. Malang : Pustaka Universitas Negeri Malang (University Press).

Sedyowati, L., Suhartanto, E., 2015, Kajian Pengaruh Sistem Drainase dan Ruang Terbuka Hijau Eksisting pada Kawasan Ruas Jalan Utama Kota Malang (Suatu Upaya Pengendalian Genangan di Daerah Perkotaan), Media Teknik Sipil, Vol. 3 No. 1, 56- 63.

Sedyowati, L., Chandrarin, G., Nugraha, Ginanjar I.K., Nugroho, Bambang, 2020, Economic efficiency of community-based flood risk management : An empirical study from Indonesia, Journal of Water and Land Development No. 46.

Sherif, M., \& Hovland, C. I. 1961. Social judgment: Assimilation and contrast effects in communication and attitude change. Yale Univer. Press.

Subarsono, A. G. (2011). Kebijakan Publik: Konsep, Teori, dan Aplikasi. Jogyakarta : Pustaka Pelajar.

Sugiyono, 2008. Metode Penelitian Kuantitatif Kualitatif Dan R \& D. Bandung : Alfabeta. Supriatna Tjahya. 2000. Strategi Pembangunan dan Kemiskinan. Jakarta: Rineka Cipta.

Suripin, 2004. Sistem Drainase Perkotaan yang Berkelanjutan. Penerbit ANDI, Yogyakarta.

Suryono, Agus. 2001. Teori dan Isu Pembangunan. Jakarta : UM

Tangkilisan, Hessel Nogi S. M.Si, Drs, 2003. Kebijakan Publik yang Membumi, Konsep, Strategi dan Kasus. Yogyakarta : Lukman Offset dan YPAPI.

Wahab, S. A. (2010). Pengantar Analisis Implementasi Kebijakan Negara. Jakarta : Rineka Cipta.

Wardhono, A., G. Pratomo, B. Prakoso, C. Qori'ah, 2012. Countermeasures Flood Disaster Sampean River Policy in Situbondo District. Journal of Law and Social Sciences (JLSS). 2(1), pp. 118-122. 